\title{
Hubungan Indeks Massa Tubuh dan Angka Kejadian Akne Vulgaris pada Siswa-siswi di SMA Frater Don Bosco Manado
}

\author{
${ }^{1}$ Ni Made Sintia Kristiani \\ ${ }^{2}$ Marlyn G. Kapantouw \\ ${ }^{2}$ Thigita A. Pandaleke
}

\begin{abstract}
${ }^{1}$ Program Studi Pendidikan Dokter Fakultas Kedokteran Universitas Sam Ratulangi Manado
${ }^{2}$ Bagian Ilmu Kesehatan Kulit dan Kelamin Fakultas Kedokteran Universitas Sam Ratulangi Email: sintia.kristiani02@gmail.com
\end{abstract}

\begin{abstract}
Acne vulgaris is a chronic inflammatory disease of the pilosebasea follicle. Although the cause of acne vulgaris is not known for certain but there are several pathogenesis suspected to have some effects on the occurrence of acne vulgaris, inter alia the increase in sebum production which is controlled by androgen hormones. Stimulation of androgen hormone production is associated with elevated level of insulin-like growth factor-1 (IGF-1). Increased IGF-1 is correlated positively with body mass index (BMI). In general, acne vulgaris begins at age 12-15 years and most occur in adolescents aged 15-18 years. This study was aimed to determine the relationship between BMI and the incidence rate of acne vulgaris in students at SMA Frater Don Bosco Manado (senior high school). This was an analytical survey observation with a cross sectional design. Subjects were 69 students obtained by using systematic random sampling. Of the 69 students suffered from acne vulgaris, there were 8 $(11.6 \%)$ with thin BMI; 50 (72.5\%) with normal BMI; and $11(15.9 \%)$ with fat and obese BMI. Conclusion: There was no significant association between BMI and the incidence of acne vulgaris among the students at SMA Frater Don Bosco Manado.
\end{abstract}

Keywords: body mass index, acne vulgaris

\begin{abstract}
Abstrak: Akne vulgaris adalah penyakit radang kronis pada folikel pilosebasea. Walaupun penyebab dari akne vulgaris belum diketahui pasti namun terdapat beberapa patogenesis yang diduga berpengaruh pada timbulnya akne vulgaris, salah satunya yaitu peningkatan produksi sebum di bawah kontrol hormon androgen. Stimulasi produksi hormon androgen berhubungan dengan peningkatan kadar insulin-like growth factor-1 (IGF-1). Peningkatan IGF-1 berkorelasi positif dengan indeks massa tubuh (IMT). Umumnya akne vulgaris dimulai pada usia 12-15 tahun dan terbanyak pada remaja usia 15-18 tahun. Penelitian ini bertujuan untuk mengetahui hubungan antara IMT dan angka kejadian akne vulgaris pada siswa-siswi di SMA Frater Don Bosco Manado. Jenis penelitian ialah observasi analitik survei dengan desain potong lintang. Subyek penelitian ialah siswa-siswi di SMA Frater Don Bosco Manado diperoleh dengan pengambilan sampel secara acak sistematis. Pada 69 subyek dengan akne vulgaris, terdapat 8 orang $(11,6 \%)$ dengan IMT kurus; 50 orang $(72,5 \%)$ dengan IMT normal; dan 11 orang $(15,9 \%)$ dengan IMT gemuk dan obesitas. Simpulan: Tidak terdapat hubungan bermakna antara IMT dan angka kejadian akne vulgaris pada siswa-siswi di SMA Frater Don Bosco Manado.
\end{abstract}

Kata kunci: indeks massa tubuh, akne vulgaris

Banyak remaja yang mempersepsikan bahwa penampilan merupakan salah satu modal terbentuknya kepercayaan diri. Salah satu contoh yang membuat penilaian itu menjadi negatif yaitu dengan timbulnya jerawat atau dalam istilah kedokteran 
disebut dengan akne vulgaris, terutama bila terdapat pada area wajah; hal tersebut dapat menjadi beban pikiran dan dapat mengakibatkan stres pada seorang remaja. ${ }^{1}$ Pada remaja yang menderita akne vulgaris sering terjadi dampak psikologis, sekitar $30-50 \%$. $^{2}$

Penyebab akne vulgaris belum diketahui secara pasti, namun diduga terdapat bebe-rapa patogenesis yang berperan terhadap kejadian akne vulgaris yaitu peningkatan produksi sebum, hiperproliferasi folikel pilosebasea, kolonisasi Propionibacterium acnes, serta proses inflamasi yang dapat ditandai dengan komedo, papula, pustula, nodul, dan seringkali bekas luka yang umumnya terjadi pada daerah wajah., ${ }^{3,4}$

Akne vulgaris merupakan penyakit kulit yang umum terjadi hampir pada semua orang di seluruh dunia. Di Amerika Serikat, tingkat prevalensi akne vulgaris ialah $85 \%$ pada usia $12-24$ tahun. ${ }^{5} \mathrm{Di}$ Indonesia akne vulgaris ditemukan pada sekitar $80 \%$ remaja. Insiden akne pada remaja bervariasi antara 30-60\% dengan insiden terbanyak pada usia 14-17 tahun pada perempuan dan 16-19 tahun pada lakilaki. ${ }^{6}$ Di Poliklinik Kulit dan Kelamin RSUP Prof. Dr. R. D. Kandou Manado terdapat angka kejadian akne vulgaris pada tahun 2009-2011 sebanyak 121 pasien dengan kelompok usia terbanyak yaitu 1524 tahun (76 pasien) dan status pendidikan terbanyak pada kelompok pelajar (73 pasien). ${ }^{7}$

Patogenesis yang diduga berpengaruh pada timbulnya akne vulgaris salah satunya yaitu peningkatan produksi sebum yang di bawah kontrol hormon androgen. ${ }^{4}$ Stimulasi produksi hormon androgen berhubungan dengan peningkatan kadar insulin-like growth factor-1 (IGF-1 yang berkorelasi positif dengan indeks massa tubuh (IMT). ${ }^{8}$ Penelitian yang dilakukan Pranitasari $^{8}$ menyatakan bahwa IMT dengan kategori overweight/obesitas berisiko untuk menderita akne vulgaris 2,423 kali lebih besar daripada IMT dengan kategori underweight/normal. Penelitian yang dilakukan oleh Astutiningsih ${ }^{9}$ di SMA Negeri 3 Klaten menyatakan tidak terdapat hubung- an antara IMT dan kejadian akne vulgaris.

Penelitian ini bertujuan untuk mengetahui adanya hubungan antara nilai IMT dan angka kejadian akne vulgaris pada remaja, dalam hal ini siswa-siswi di SMA Frater Don Bosco Manado.

\section{METODE PENELITIAN}

Jenis penelitian yang digunakan yaitu observasi analitik survei dengan desain potong lintang. Penelitian dilaksanakan di SMA Frater Don Bosco Manado. Subyek penelitian yaitu siswa-siswi di SMA Frater Don Bosco Manado tahun ajaran 2017/ 2018 dengan metode pengambilan sampel secara acak sistematis/systematic random sampling serta memperhatikan kriteria inklusi dan eksklusi.

\section{HASIL PENELITIAN}

Berdasarkan hasil penelitian yang dilakukan di SMA Frater Don Bosco Manado tahun 2017 diperoleh subyek penelitian sebanyak 81 orang, namun yang memenuhi kriteria inklusi sebanyak 69 orang. Semua subyek menderita akne vulgaris dengan derajat ringan, sedang, dan berat. Hasil penelitian disajikan dalam bentuk tabel dan deskriptif.

Data pada Tabel 1 menunjukkan bahwa dari total 69 subyek, mayoritas berusia 16 tahun, yaitu sebanyak 33 orang $(47,8 \%)$, diikuti yang berusia 15 tahun sebanyak 23 orang $(33,3 \%)$, dan yang berusia 17 tahun sebanyak 13 orang $(18,8 \%)$.

Tabel 1. Distribusi data subyek penelitian berdasarkan usia

\begin{tabular}{ccc}
\hline Usia (tahun) & $\mathbf{n}$ & $\mathbf{\%}$ \\
\hline 15 & 23 & 33,3 \\
16 & 33 & 47,8 \\
17 & 13 & 18,8 \\
Total & $\mathbf{6 9}$ & $\mathbf{1 0 0}$ \\
\hline
\end{tabular}

Data pada Tabel 2 menunjukkan bahwa dari total 69 subyek, mayoritas berjenis kelamin perempuan yaitu sebanyak 36 orang $(52,2 \%)$, sedangkan laki-laki sebanyak 33 orang $(47,8 \%)$. 
Tabel 2. Distribusi data subyek penelitian berdasarkan jenis kelamin

\begin{tabular}{ccc}
\hline Jenis kelamin & n & \% \\
\hline Laki-laki & 33 & 47,8 \\
Perempuan & 36 & 52,2 \\
Total & 69 & 100 \\
\hline
\end{tabular}

Data pada Tabel 3 menunjukkan bahwa hasil IMT terbanyak dari total 69 subyek ialah IMT normal yaitu sebanyak 50 orang $(72,5 \%)$, diikuti oleh IMT gemuk dan obesitas sebanyak 11 orang $(15,9 \%)$, dan IMT kurus sebanyak 8 orang $(11,6 \%)$.

Tabel 3. Gambaran IMT pada subyek penelitian

\begin{tabular}{ccc}
\hline IMT & n & \% \\
\hline Kurus & 8 & 11,6 \\
Normal & 50 & 72,5 \\
Gemuk dan obesitas & 11 & 15,9 \\
Total & 69 & 100 \\
\hline
\end{tabular}

Pada 69 subyek penelitian didapatkan semuanya menderita akne vulgaris dengan derajat ringan, sedang, dan berat. Data pada Tabel 4 menunjukkan bahwa dari total 69 subyek, mayoritas menderita akne ringan, yaitu sebanyak 53 orang $(76,8 \%)$, diikuti akne sedang sebanyak 14 orang $(20,3 \%)$, dan akne berat sebanyak 2 orang $(2,9 \%)$.

Tabel 4. Gambaran derajat akne vulgaris pada subyek penelitian

\begin{tabular}{ccc}
\hline $\begin{array}{c}\text { Derajat } \\
\text { akne vulgaris }\end{array}$ & n & \% \\
\hline Ringan & 53 & 76,8 \\
Sedang & 14 & 20,3 \\
Berat & 2 & 2,9 \\
Total & 69 & 100 \\
\hline
\end{tabular}

Hubungan IMT dengan angka kejadian akne vulgaris pada siswa-siswi di SMA Frater Don Bosco Manado dianalisis dengan uji korelasi Spearman Rank yang mendapatkan nilai signifikansi/Sig.2-tailed sebesar 0,233 $(>0,05)$ yang menunjukkan tidak terdapat hubungan bermakna antara IMT dan angka kejadian akne vulgaris pada siswa-siswi di SMA Frater Don Bosco
Manado. Untuk nilai kekuatan hubungan/ Correlation Coefficient didapatkan sebesar 0,145 yang menunjukkan bahwa tidak terdapat hubungan atau korelasi sangat lemah antara IMT dan angka kejadian akne vulgaris pada siswa-siswi di SMA Frater Don Bosco Manado. Untuk arah hubungan IMT dan akne vulgaris didapatkan angka koefisien korelasi bernilai positif yaitu 0,145 sehingga arah hubungan keduanya bersifat searah artinya semakin meningkat nilai IMT maka semakin meningkat angka kejadian akne vulgaris.

\section{BAHASAN}

Hasil penelitian ini sejalan dengan penelitian yang dilakukan Astutiningsih ${ }^{9}$ yang menyatakan bahwa tidak terdapat hubungan antara IMT dan angka kejadian akne vulgaris di SMA Negeri 3 Klaten. Penelitian yang dilakukan oleh Ninggar ${ }^{10}$ menyatakan bahwa terdapat korelasi lemah yang bermakna antara IMT dan derajat keparahan akne vulgaris. Indeks massa tubuh mampu memengaruhi skor derajat keparahan akne sebesar 13,2\%, sedangkan $86,8 \%$ dipengaruhi oleh faktor-faktor lain. Faktor-faktor lain yang dapat memengaruhi terjadinya akne vulgaris salah satunya ialah faktor genetik. ${ }^{2-4,11}$ Penelitian yang dilakukan oleh Muyassaroh ${ }^{12}$ di SMA Negeri 2 Blitar menyatakan bahwa hasil dari nilai signifikansi antara faktor genetik dengan kejadian akne vulgaris/Sig. 2-tailed sebesar $0,001(<0,05)$ yang menunjukkan berkorelasi atau terdapat hubungan bermakna antara faktor genetik dan angka kejadian akne vulgaris. Selain faktor genetik terdapat beberapa faktor lain yang memengaruhi terjadinya akne vulgaris yaitu penggunaan kosmetik yang berganti-ganti, makanan tinggi lemak, tindakan mekanik seperti menggosok atau menggaruk akne, frekuensi fasial, dan tingkat kecemasan. ${ }^{13,14}$ Untuk hubungan makanan yang tinggi lemak dengan kejadian akne vulgaris seperti coklat, susu, permen, dll belum diketahui secara pasti dan masih membutuhkan penelitian lebih lanjut untuk melihat apakah terdapT hubungan antara faktor makanan dan kejadian akne vulgaris. ${ }^{2}$ Hal ini juga 
sesuai dengan teori yang menyatakan bahwa penyebab akne vulgaris masih belum diketahui. Beberapa penyebab yang diduga terlibat ialah genetik, stres, hormonal, iklim/suhu/kelembaban, kosmetik, dan obat-obatan. ${ }^{4}$ Selain faktor-faktor tersebut, menggosok bagian wajah dengan tangan, pakaian seperti kerah baju secara berulang atau penekanan yang dapat ditimbulkan pada wajah ketika memakai helm atau topi juga dapat menimbulkan akne vulgaris yang disebut acne mechanica karena hal-hal tersebut dapat mengiritasi epitel folikuler dan dapat terjadi pembentukan komedo. ${ }^{2}$

Dalam penelitian ini tidak didapatkan hubungan antara IMT dan angka kejadian akne vulgaris di SMA Frater Don Bosco Manado. Hal ini dapat disebabkan selain karena penyebab dari akne vulgaris yang belum diketahui secara pasti juga ada faktor-faktor lain yang diduga dapat menyebabkan akne vulgaris.

\section{SIMPULAN}

Berdasarkan hasil penellitian dapat disimpulkan bahwa tidak terdapat hubungan bermakna antara indeks massa tubuh dan angka kejadian akne vulgaris pada siswa-siswi di SMA Frater Don Bosco Manado.

\section{SARAN}

Disarankan untuk melakukan penelitian tentang hubungan resistensi insulin dan kejadian akne vulgaris.

Tidak terbuktinya bahwa IMT berpengaruh terhadap angka kejadian akne vulgaris bukan berarti dapat mengesampingkan faktor tersebut dalam mengedukasi pasien, karena dalam hasil uji korelasi Spearman Rank didapatkan arah hubungan yang positif artinya semakin meningkat nilai IMT maka semakin meningkat angka kejadian akne vulgaris.

\section{DAFTAR PUSTAKA}

1. Wahyuni E. Hubungan persepsi tentang jerawat dengan kepercayaan diri remaja akhir [Skripsi]. Jakarta: Fakultas Psikologi Universitas Islam Negeri
Syarif Hidayatullah; 2007.

2. Goldsmith LA, Katz SI, Gilchrest BA, Paller AS, Leffell DJ, Wolff K. Acne vulgaris and acneiform erup-tions. Zaenglein AL, Graber EM, Thiboutot DM, editors. Fitzpatrick's Dermatology in General Medicine (8th ed). New York: McGraw-Hill; 2012; p. 897-913.

3. Wolff K, Johnson RA, Saavedra AP. Fitzpatrick's Color Atlas and Synopsis of Clinical Dermatology (7th ed). New York: McGraw-Hill Education, 2013; p. 2-17.

4. Sitohang I, Wasitatmadja S. Akne vulgaris. In: Menaldi S, Bramono K, Indriatmi W, editors. Ilmu Penyakit Kulit dan Kelamin (7th ed). Jakarta: FKUI, 2016; p. 288-90.

5. Zari S, Turkistani A. Acne vulgaris in jeddah medical students: prevalence, severity, self-report, and treatment practices. Cosmetics, dermatological sciences and applications. 2017;7:67-76.

6. Dhamayanti M. Overview adolescent health problems and services. 10 September 2013. [cited 2017 Aug 9]. Available from: http://www.idai.or.id/artikel/ seputar-kesehatan-anak/overviewadolescent-health-problems-andservices

7. Mizwar M. Profil akne vulgaris di RSUP Prof. Dr. R. D. Kandou Manado periode 2009-2011. eCl. 2013;1:6.

8. Pranitasari A. Hubungan antara indeks massa tubuh (IMT) dengan akne vulgaris [Skripsi]. Surakarta: Fakultas Kedokteran Universitas Sebelas Maret; 2011.

9. Astutiningsih S. Hubungan antara indeks massa tubuh (IMT) dengan timbulnya akne vulgaris pada siswa-siswi SMA Negeri 3 Klaten [Skripsi]. Surakarta: Fakultas Kedokteran Universitas Muhammadiyah; 2014.

10. Ninggar G. Korelasi antara indeks massa tubuh dengan derajat keparahn akne pada penderita akne vulgaris [Skripsi]. Yogyakarta: Fakultas Kedokteran Universitas Gadjah Mada; 2014.

11. James WD, Berger TG, Elston DM, Neuhaus IM. Andrew's Diseases of the Skin Clinical Dermatology (12th ed). Philadelphia: Elsevier, 2016; p. 225-32.

12. Muyassaroh EL. Faktor-faktor yang 
Kristiani, Kapantouw, Pandaleke: Hubungan indeks massa tubuh dan...

mempengaruhi kejadian acne vulgaris pada siswa kelas x SMA Negeri 2 Kota Blitar. Jurnal Strada. 2014;3:1-8.

13. Sampelan M. Hubungan timbulnya acne vulgaris dengan tingkat kecemasan pada remaja di SMP N 1 Likupang
Timur. e-Journal Keperawatan. 2017;5:3-5.

14. Suryadi T. Kejadian dan faktor resiko akne vulgaris. Media Medika Indonesiana. 2008;43:40. 